軽金属 第50巻 第 9 号 $(2000) ， 456-461$

\title{
AZ31 グネシウム合金板の深絞り成形性
}

$\begin{array}{lrrr}\text { 相田 } & \text { 収平*.田辺 } & \text { 筧* }^{*} \text {. 須貝 } & \text { 裕之* } \\ \text { 高野 } & \text { 格*.大貫 } & \text { 秀樹**.小林 } & \text { 勝*** }\end{array}$

Journal of Japan Institute of Light Metals, Vol. 50, No. 9 (2000), pp. 456-461

\section{Deep-drawability of cup on AZ31 magnesium alloy plate}

\author{
Shuhei AIDA*, Hiroshi TANABE*, Hiroyuki SUGAI* \\ Itaru TAKANO*, Hideki OHNUKI** and Masaru KOBAYASHI***
}

\begin{abstract}
Recently, magnesium alloys are often applied in the auto industries and electric appliances. Most of them are manufactured by using some casting methods. But, from the viewpoints of productivity and quality of product, it is easily expected that the development of press forming technology is strongly required along with other metals and alloys. It is therefore important to grasp the plasticity of magnesium alloys. The purpose of this work is to investigate the possibility of press forming on AZ31 magnesium alloy plate. So, the tensile tests were performed to understand its basic material characteristics, and press forming tests were strived to improve its deep-drawability. The results of this study are summarized as follows. From the tensile test, the elongation of AZ31 was about $10 \%$ at room temperature, but the elongation increases in increasing temperature and amounts to $80 \sim 90 \%$ at $473 \mathrm{~K}$. It was also found that the limit of drawing ratio of AZ31 plate resulted in 3.2 by heating the die at $473 \mathrm{~K}$ or above and by cooling the punch at room temperature or below.
\end{abstract}

(Received March 16, 2000)

Keywords: draw, AZ31B magnesium alloy, deep-drawability, tensile property

\section{1. 緒言}

マグネシウム合金は，実用金属としては最も軽い材料であ るとともに，再生に要するエネルギーが新塊製造エネルギー の $4 \%$ 程度で斉むといったリサイクル性にも富んだ金属であ るなどの特長を有して拈り，近年では欧米を中心として自動 車部品への適用が多く見られる。一方, 国内では自動車部品 のほか，ノートパソコソやミニディスクプレーヤなど携帯情 報家電の筐体への採用例が注目を集めている。ところで，こ れらの多くはダイカストあるいは射出成形法（チクソモール ディング法）で作られている。これは，マグネシウムの結晶 構造が最密六方晶であることに起因する，常温での塑性加工 性の悪さのためにプレス成形による加工技術の普及が遅れて いること，およびマグネシウム合金板の塑性加工成形性につ いての報告がそれ医ど多くはなく1),2)，加工データも不足し ているなどの理由によると考无られる。しかし生産性や製品 の均質化などの観点から，他の金属材料と同様に今後はプレ ス成形加工への要求が高まっていくものと予想される。

本研究では，これまでにあまり試みられてはいなかったマ グネシウム合金のプレス加工の実用化を検討すべく，代表的 なマグネシウム合金展伸材である AZ31合金を取上げ，引張
Table 1 Chemical composition of sample plate

\begin{tabular}{c|c|c|c|c}
\hline \hline \multirow{2}{*}{ Material } & \multicolumn{4}{|c}{ Chemical composition (mass\%) } \\
\cline { 2 - 5 } & $\mathrm{Al}$ & $\mathrm{Zn}$ & $\mathrm{Mn}$ & $\mathrm{Mg}$ \\
\hline AZ31B-H24 & 3.3 & 1.1 & 0.5 & $\mathrm{Bal}$. \\
\hline
\end{tabular}

試験による材料の基本的な特性を明らかにするとともに，プ レス加工による深絞り成形性試験を行った結果について報告 する。

\section{2. 実験方法}

実験に供したマグネシウム合金王延材の化学組成を Table 1 に示すとともに Fig. 1 Kは金属組織観察写真を示 す。供試材は板厚約 $0.88 \mathrm{~mm}$ の AZ31B $(\mathrm{Mg}-3 \mathrm{Al}-1 \mathrm{Zn})$ 合金 で，王延後に一部焼なましを行った板材（H24材）であり， 硬さはHV65～70程度，結晶粒径は执执むね10～20 $\mu \mathrm{m}$ とな っている。むた，加工性と関連の深い供試材の集合組織につ いても湘定を行った。測定面は底面，柱面特よび鍾面の各面 について行ったが，ここでは\{0001\}面（底面）について結晶 格子の配列方向を示した極点図を Fig. 2 に示す。図で明ら

\footnotetext{
* 新潟県工業技術総合研究所（干950-0915 新潟市鐙西 1-11-1）。 Industrial Research Institute of Niigata Prefecture (1 11-1, Abumi-nishi, Niigata-shi, Niigata 950-0915).

** 新渴県工業技術総合研究所（新渴市）[現在：珠)東陽理化学研究所（燕市）]。Industrial Research Institute of Niigata Prefecture (Niigatashi, Niigata).

*** 千葉工業大学（習志野市）。Chiba Institute of Technology（Narashino-shi, Chiba）.
} 


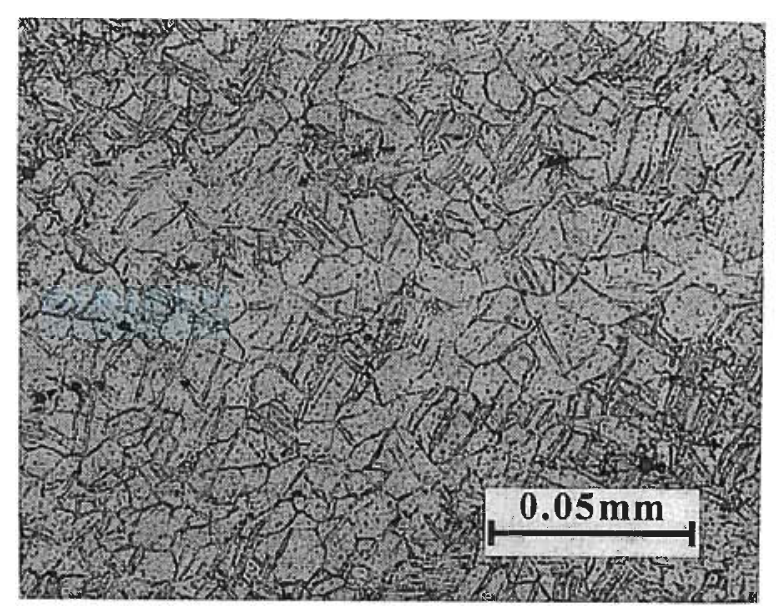

Fig. 1 Cross sectional photograph of AZ31B-H24 magnesium alloy plate.

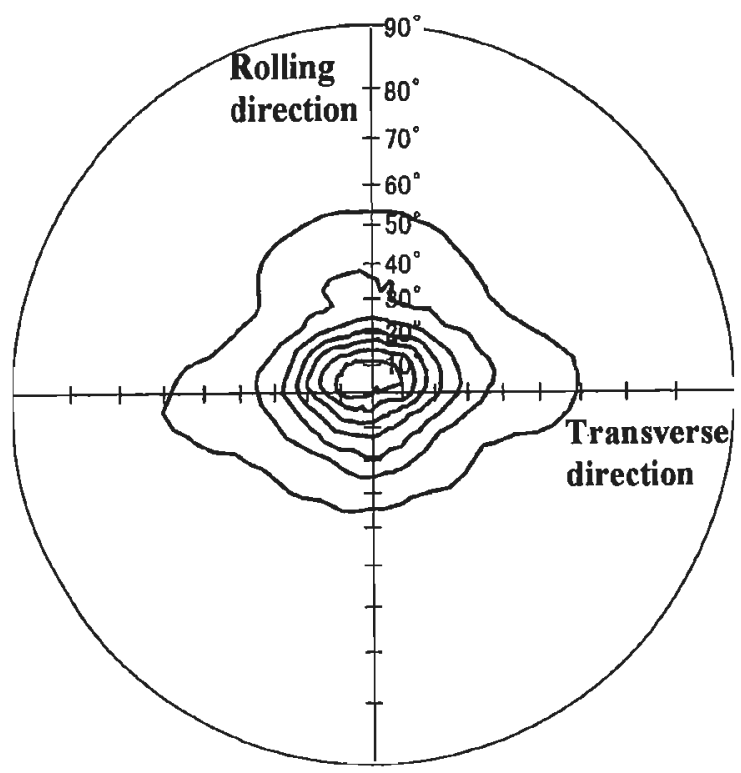

Fig. $2\{0001\}$ pole figure of AZ31B-H24 magnesium alloy plate.

かなように，結晶の底面が圧延板の板面にほぼ平行な集合組 織になっており，压延工程によって結晶粒の結晶方位が揃っ たことがらかがわれる。このような材料を用いて引張試験お 上び深校り成形性の両試験を行った。

引張試験は，板材の圧延方向に対してそれぞれ $0^{\circ}, 45^{\circ}$, $90^{\circ}$ 方向にJIS Z 2201 にる $13 \mathrm{~B}$ 号試験片（平行部幅 12.5 $\mathrm{mm}$, 僄点間距離 $50 \mathrm{~mm}$ ) を採取し, 引張試験機（インスト ロン5582型）によりクロスーッド速度 $8.3 \times 10^{-2} \mathrm{~mm} / \mathrm{s}$ の条 件で, 室温から $473 \mathrm{~K}$ の温度範囲で行い, 引張強さと破断伸 びを求めた。また同様の試験片呿よび温度範囲に括いて, ク ロスーッド速度 $4.2 \times 10^{-2} \mathrm{~mm} / \mathrm{s}$ の条件により, 深较り成形 性と関連のある加工硬化指数 $n$ 值, およびランクフォード值 r值を求めた。

一方, 深较り成形性試験については, 複動型油圧プレス

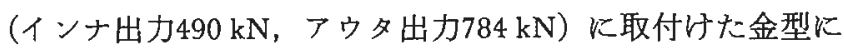
より円筒および角筒の深絞り試験を行い，下記に示寸各成形 条件に括ける限界絞り比 $L D R$ を求めることにより評価し た。

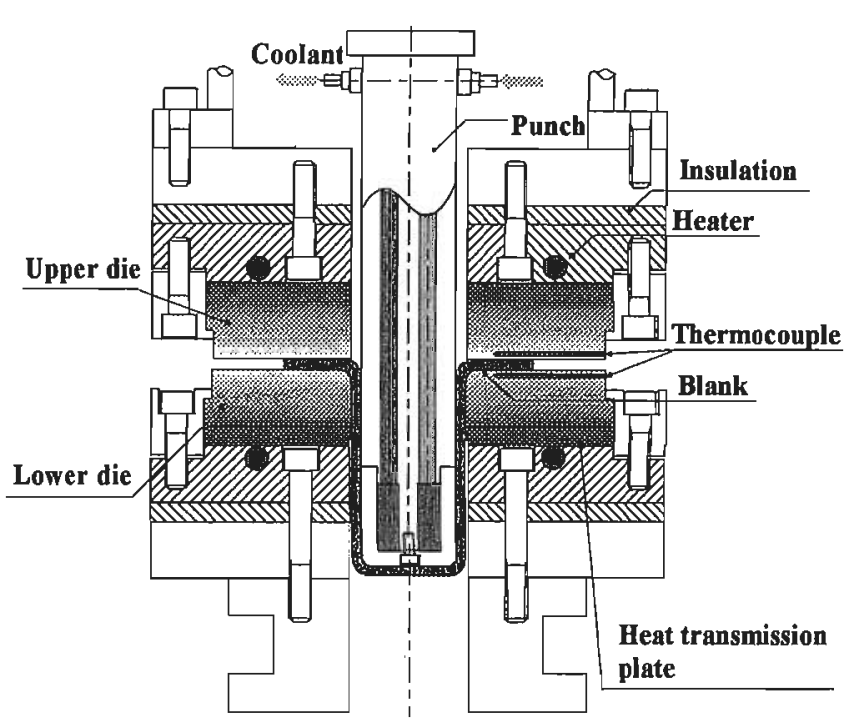

Fig. 3 Schematic illustration of drawing method.

Fig. 3 亿金型の断面構造を示す。金型は平面ダイス構造で あり，油压によりしわ押さ方力を一定に保つことができる。 加熱方法については，円形に曲げた棒状ヒ一タをヒータホル ダに組込み，伝熱板を介してダイスとしわ押さ光の両方を加 熱するとともに，温度制御はダイスとしわ押さ兄の表面近傍 に熱電対を取付け，PID方式沈よるフィードン゙ック制御を 行っている。また，パンチは内部に水を流すことで温度調節 ができる構造とし，温度調節機によりパンチ頭部の温度を $273 \mathrm{~K}$ 近傍から $373 \mathrm{~K}$ 近傍をで制御している。

実験に際しては，金型表面が所定の温度になるまで放固す るとともに，温度調節した水をパンチ内に 5 分間程度流し， 一定温度になったことを確認した後，水を流し続けることで パソチの温度を保持して皎り加工を行った。

成形条件はしわ押さ元力を $19.6 \mathrm{kN}$ 一定とし，絞り速度は 約1.0 15.7 mm/s の範围で行った。また成形温度はダイス, しわ押さ兄とも室温〜 $523 \mathrm{~K}$ の温度範用で行らとともに， ハ ソチ温度を $277 \mathrm{~K}, 303 \mathrm{~K}, 373 \mathrm{~K}$ の各温度に設定し, パンチ 冷却効果の有無の比較についても検討を行った。

工具各部の寸法は，円筒深絞り用金型ではパンチ径 60.4 $\mathrm{mm}$, パンチ肩半径は $6.0 \mathrm{~mm}$, ダイス穴径は $62.5 \mathrm{~mm}$, ダイ ス肩半径 $6.0 \mathrm{~mm}$ とした。また，角筒深较り用金型について は口 $65.0 \mathrm{~mm}$ ，パソチ肩半径扣よびパチコーナ肩半径 10.0 $\mathrm{mm}$ のパソチに対し, $\square 67.8 \mathrm{~mm}$, ダイス局半径 $10.0 \mathrm{~mm}$ の ダイスを用いた。な挌，絞り加工時の潤滑剤については，冷 間王延鋼板やステンレス鋼板などに比べて高い温度で加工実 験を行らこと、およびマグネシゥム合金の皎り加工がまだ広 く実用化されて打らず，これに適した市販の潤滑剤は見当た らなかった。そのために今回の実験には5 $23 \mathrm{~K}$ の温度に対応 でき，かつ潤滑性の良好なテフロンシート（厚さ0.05 mm） を用いた。

\section{3. 実験結果および考察}

\section{1 引張試験結果}

Fig. 4 K AZ31B-H24材について压延方向に対する採取角 度と引張強さお゙よび破断伸びの温度依存性を示す。引張強さ は室温で $348 \mathrm{MPa}\left(90^{\circ}\right.$ 方向) であるが，試駼温度の上昇と 


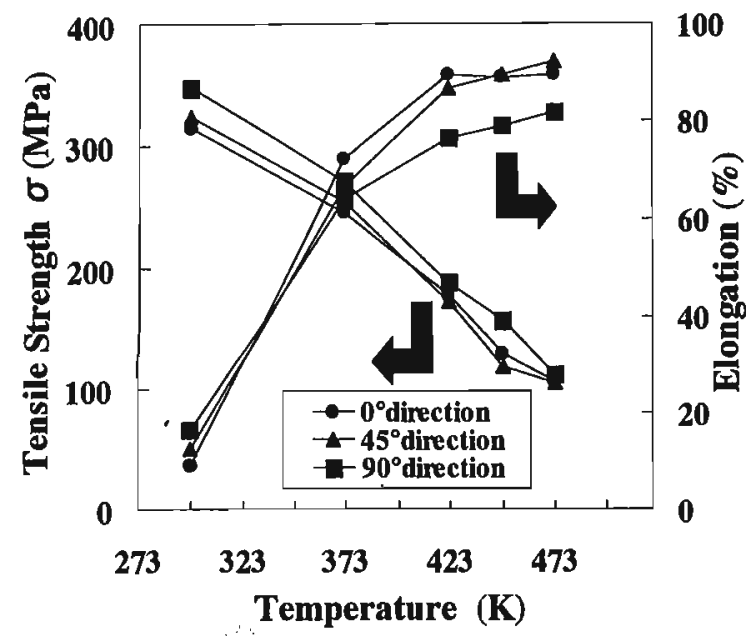

Fig. 4 Relationship between temperature and tensile strength and elongation.

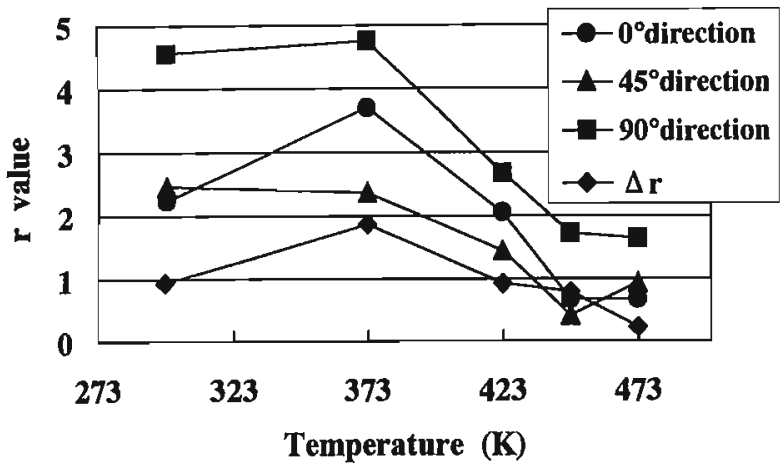

Fig. 5 Relationship between temperature and $r$ value.

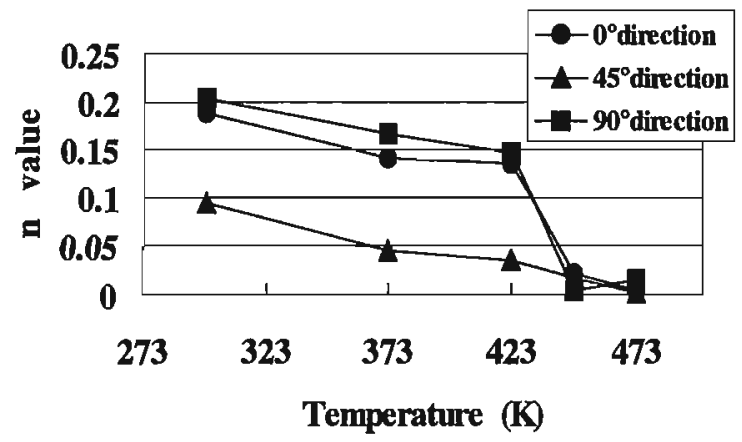

Fig. 6 Relationship between temperature and $n$ value.

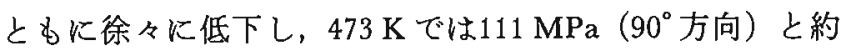
1/3程度の強度にまで低下している。一方, 伸びは, 室温で は約10〜15\%程度の伸びにとどまるのに対し，373 K までは 温度の上昇とともに注活直線的に增加し, 約70\%程度の伸び が得られる。それ以上の温度ではその增加がやや鈍化する が，473 K では80 90\%の伸びが得られるよらになる。これ は, 温度が高くなるにつれて, 結晶粒に和ける底面すべり以 外での臨界せん断応力が低下し，他のすべり面が現れてくる ことに起因していると考兄られる。一方，材料の採取角度に 上る違いについては, 引張強さは $90^{\circ}$ 方向が高く $0^{\circ}, 45^{\circ}$ 方向 は低い傾向が見られる。伸びはそれとは逆に， $0^{\circ} ， 45^{\circ}$ 方向が 大きく $90^{\circ}$ 方向が低くなっている。

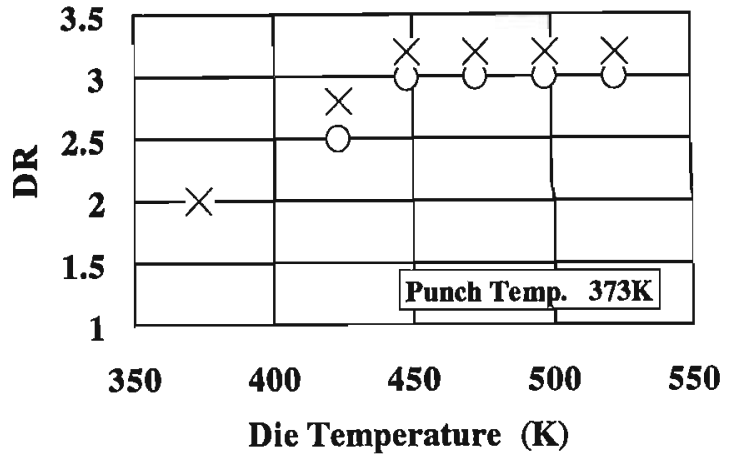

Fig. 7 Relationship between die temperature and DR. Punch temperature: $373 \mathrm{~K}$.

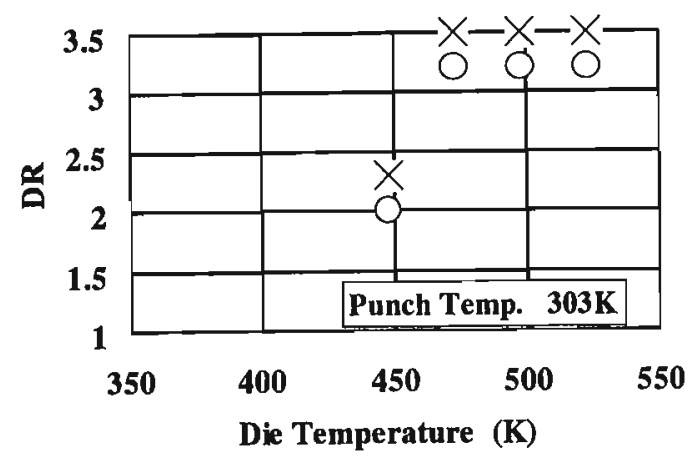

Fig. 8 Relationship between die temperature and DR. Punch temperature: $303 \mathrm{~K}$.

Fig. 5 には材料の板面異方性特よび深皎り性と強い相関を 持っている $r$ 值について試験温度との関係を示している。室 温から $373 \mathrm{~K}$ 程度までの範囲では, 材料の採取角度間での 値の差が大きいが，それ以上 $473 \mathrm{~K}$ までに拀いては徐々にこ の差が縮まってくるとともに，r=1の值に収束している様 子がうかが克る。

また Fig. 6 には，r值と並んでプレス成形性と相関のある 特性值である加工硬化指数 $n$ 值の温度依存性について示して いる。この場合も $r$ 值と同様に, 室温での值と $473 \mathrm{~K} て ゙ は$ 異 なった值を示し，室温では $0^{\circ}, 90^{\circ}$ 方向で約 0.2 程度である が，473 K では板の採取角度にかかわらずほぼ 0 となってい る。

\section{2 深絞り成形性試験結果}

まず深校り成形の基本である円筒深校りを取上げ，ダイス 拈よびパソチの設定温度を变化させて絞り加工を試みた場合 についての絞り比 $D R$ を，パンチの設定温度別飞 Fig. 7〜 Fig. 9 亿示す。図中, 材料が加工途中で破断せずに円筒容器 の形状に校り得たものを○印で示し, 途中で破断した場合を ×印で示している。な拉，校り速度は $2.5 \mathrm{~mm} / \mathrm{s} て ゙$ て行った。

先に示した引張試験の結果からもらかが兄るよらに，室温 では材料の伸びがあまりないために饺り加工は不可能であ る。しかし，パンチ温度が373 K (Fig. 7) では, ダイス温 度 $423 \mathrm{~K}$ で絞り比 $2.5 か ゙$ 得られ，それ以上のダイス温度では 絞り比 3.0 あ゙加工が可能となっている。また，パンチを水 冷することにより温度を $303 \mathrm{~K}$ に設定した場合（Fig. 8）で は, ダイス温度 $423 \mathrm{~K}$ 以下の温度領域では加工中に割れが発 生するが， $448 \mathrm{~K}$ では $L D R 2.0$ が得られ， $473 \mathrm{~K}$ 以上の温度 


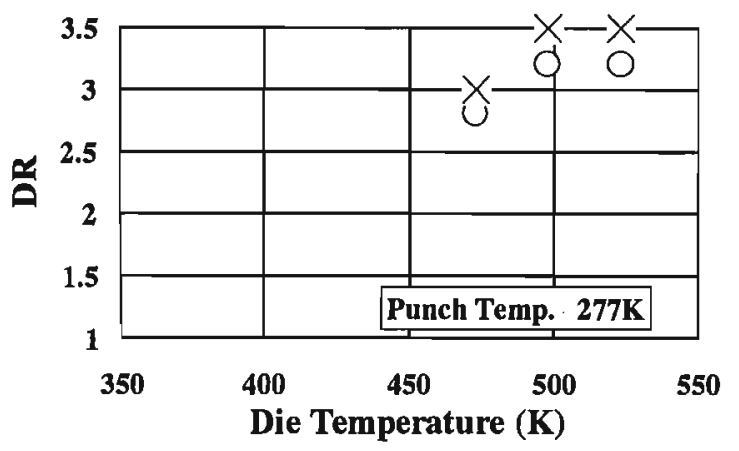

Fig. 9 Relationship between die temperature and DR. Punch temperature: $277 \mathrm{~K}$.

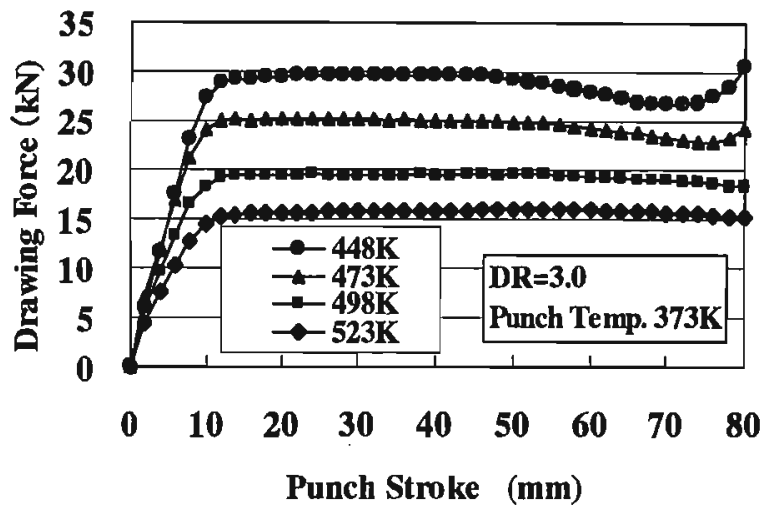

Fig. 10 Relationship between punch stroke and drawing force.

領域ではLDR 3.2 といった大きな絞り比が得られるよらにな る。パンチ温度をさらに下げ，277 K とした場合を Fig. 9 に示すが， $448 \mathrm{~K}$ 以下のダイス温度では絞り加工ができない のに対し， $473 \mathrm{~K} て ゙ L D R ~ 2.8 か ゙$ 得られ，それょり高い温度領 域では LDR 3.2が得られている。

ダイスの加熱により，間接的にマグネシウム合金ブランク 材を加熱し，村料の伸びを大きくすることで絞り加工が可能 になると考兄られるが，高温領域では伸びの增加と同時に材 料の引張強さも低下してしまう。Fig. 7 Fig. 9 の結果の比 較から明らかであるが，ダイス温度が $473 \mathrm{~K}$ 以上の温度領域 に叔いては，パンチ温度が373 K (Fig. 7) では LDRが3.0に とどまっているが，Fig. 8 拉よび Fig. 9 に示すよ5に，パン チを冷却することで絞り加工時に最も破断の危険が大さい部 位の一つであるパンチ頭部の強度低下を抑えることができる ために, LDR 3.2 と皎り性が向上するものと考竞られる ${ }^{3), 4) 。 ~}$ しかしながら，パンチ冷却については，フランジ部の変形抵 抗とパンチ頭部近傍に淤ける破断力とのバランスによりその 効果が現れる。マグネシウム合金は室温近傍の温度領域で は，材料の伸びが得られず脆性的な破壊をする。すなわちダ イスの温度が低い領域では, 材料のフランジ部に拈いては, 加熱による材料の伸びの効果よりるパンチ冷却によって生じ る脆性破壊の影響が強く現れてしまうために，加工途中にパ ソチ肩部で破断を生じ，限界较り比 $L D R$ が小さくなってし まうと考光られる。Fig. 7 Fig. 9 に示したがイス温度 448 $\mathrm{K}$ の場合では，この影響をよく反映しており，それぞれパ ソチ温度 $373 \mathrm{~K}$ で $L D R 3.0$, パンチ温度 $303 \mathrm{~K}$ では $L D R 2.0$ と低下し,さらにパンチ温度 $277 \mathrm{~K}$ と最も低い場合には絞り

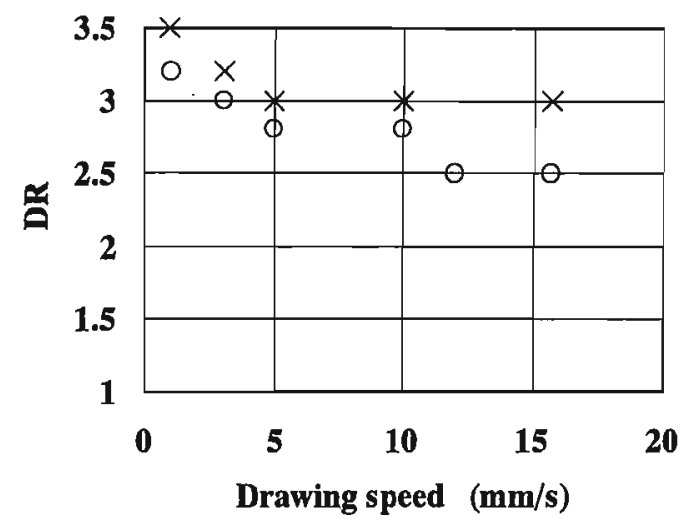

Fig. 11 Relationship between drawing speed and DR.

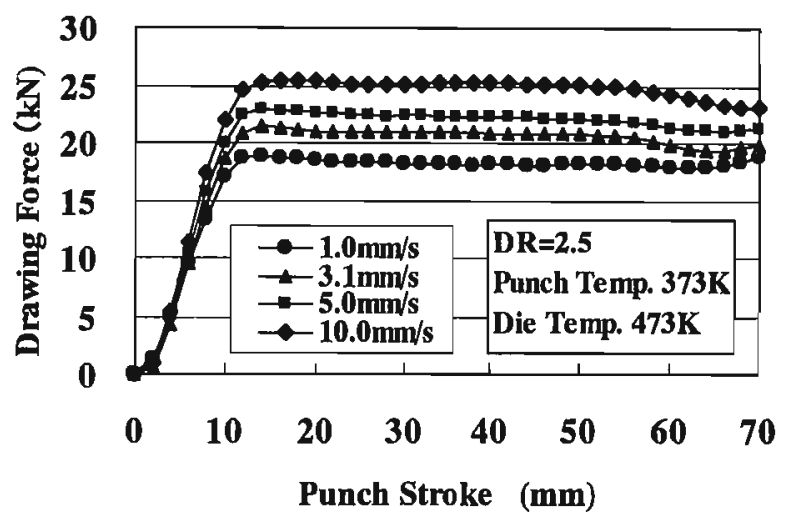

Fig. 12 Relationship between punch stroke and drawing force.

加工が不可能となっている。

また Fig. 10K，パンチ温度 $373 \mathrm{~K}$ ，絞り比 3.0 とし，ダイ ス温度を $448 \mathrm{~K} \sim 523 \mathrm{~K}$ まで $25 \mathrm{~K}$ ステップで变化させた場合 の各温度に打けるパンチストロークと絞り力の関係を示す。 各成形条件とも，ストロークがパン側壁部とブランク材の 接する位置が円筒部となる深さである約 $12 \mathrm{~mm}$ に達した後 は，ほぼ絞り力が一定となっている。図中に示した各温度条 件において校り加工は可能であるが，ダイス温度を高く設定 するに従って最大絞り力は低下し， $523 \mathrm{~K} て ゙ は$ 約 $15.7 \mathrm{kN}$ と $448 \mathrm{~K}$ の場合の約 $1 / 2$ 程度になって掞り，加熱に上る材料の 伸びの増加と変形抵抗の低減効果がこの結果からもらかがえ る。

以上の実験は，絞り速度 $2.5 \mathrm{~mm} / \mathrm{s}$ で行っているが，マグ ネシウム合金の絞り加工の実用化を考光た場合には, 生産効 率の点などから，さらに速い校り速度が要求されるものと予 想される。そこで，絞り速度の依存性についても検討を行っ た。Fig. 11には，絞り速度を約1.0〜 $15.7 \mathrm{~mm} / \mathrm{s}$ の範囲で変 化させた場合の絞り比 $D R$ と絞り速度との関係について示す とともに, Fig. 12に絞り速度を变化させた場合のパンチス トロークと絞りカの関係を示す。絞り速度が增加すると, 深 饺り限界が徐々飞低下していく傾向が見られ，10.0 mm/s で $L D R 2.8,15.7 \mathrm{~mm} / \mathrm{s}$ で LDR 2.5 となっている。また, 絞り 力は速度の增加従って大きくなっていることからも，速度 の增加炕よる限界絞り比 $L D R$ の低下がうかがわれる。しか しながら，ステンレス鋼板などの校り比が 2.0 程度であるこ と年を考虑すると，本実験の速度範囲においては十分実用的 


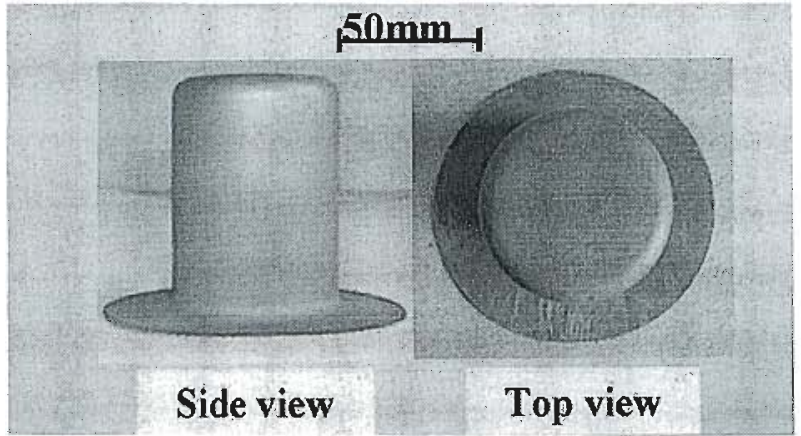

Fig. 13 Photograph of drawing sample.

な絞り性を有していると考学られる。

通常の絞り速度の範围内では, 校り速度が材料の変形に与 兄る影響は少なく，絞り速度の依存性は主に潤滑性の速度効 果と関連性があるとされている。油性の潤滑剤では，絞り速 度の增加に上り潤滑剤の摩擦抵抗が減少し, フランジ拈よび ダイス肩部での変形抵抗が減少し交り性の向上が見られる6)。 しかし本実験に拈いては，潤滑剤としてテフロンシートを用 いて和り，摩擦抵抗の速度依存性は少ない之考兄られる。本 実験結果では, 饺り速度が大きくなるに従って絞り力が大き くなっている傾向が現れているが，これは，村料の塑性変形 に関寸る特性以外飞, 工具と材料間の摩擦抵抗や潤滑条件な ど複雑な要素が影響しているものと考兄られる。

Fig. 13にはダイス温度 $473 \mathrm{~K}$ ，パンチ温度 $373 \mathrm{~K}$ の成形条 件による加工サンプルを示す。絞り比は3.0，パンチスト口 一クは80 mmで，絞りきっていないためにフランジ部が残 っている。ところでブランク材はマグネシウム合金であり， その良好な熱厷導特性と薄板であることなどからダイス温度 と加工温度はほぼ同じと考学ることができる。したがって， Fig. 13に示した加工についてフランジ部からダイス肩部に 执いては核涪473 K で加工したと見なせる。

ところで，Fig. 5 図中の $\Delta r$ は板面の塑性異方性を表す値 であり，式(1)で表される7)。

$$
\Delta r=\left(r_{0^{\circ}}+r_{90^{\circ}}-2 r_{45^{\circ}}\right) / 2
$$

この $\Delta r$ と深校り加工時のフランジ部分に批ける形状との 間には， $\Delta r>0$ では $0^{\circ}, 90^{\circ}$ 方向に耳が発生し， $\Delta r<0$ では $45^{\circ}$ 方向に耳が発生するのに対して, $\Delta r=0$ では耳が生じな い，すなわち異方性が解消され等方的な性質になるといった 関係がある7),8)。本研究で使用したAZ31材では， $\Delta r$ は室温

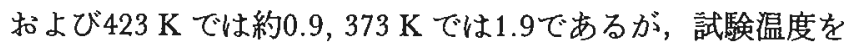
$473 \mathrm{~K}$ まで上昇させると0.2程度まで減少している。

Fig. 13に示した加工品では, Top viewでわかるようにフ ランジ形状は注济円形となって扮り，この加工温度では異方 性が解消され等方的になっていることがうかがえるが，この ことと, 前述の Fig. 5 の単軸引張試験で得られた $r$ 值とは上 く一致している。

Fig. 14には，ダイス絞り加工品の断面に括けるビッカー ス硬さの分布を示す。図中に物ける横軸の測定長 $L(\mathrm{~mm})$ は 校り加工品底中心部を 0 とし，底部半径方向から側壁部方向 へと $2 \mathrm{~mm}$ 間隔で測定を行っている。絞り加工において底部 は等二軸引張状態となる8)が，中心部 $(L=0)$ では変形を受 けないことになり，ほぼ加工前の供試材の硬さに等しいと考

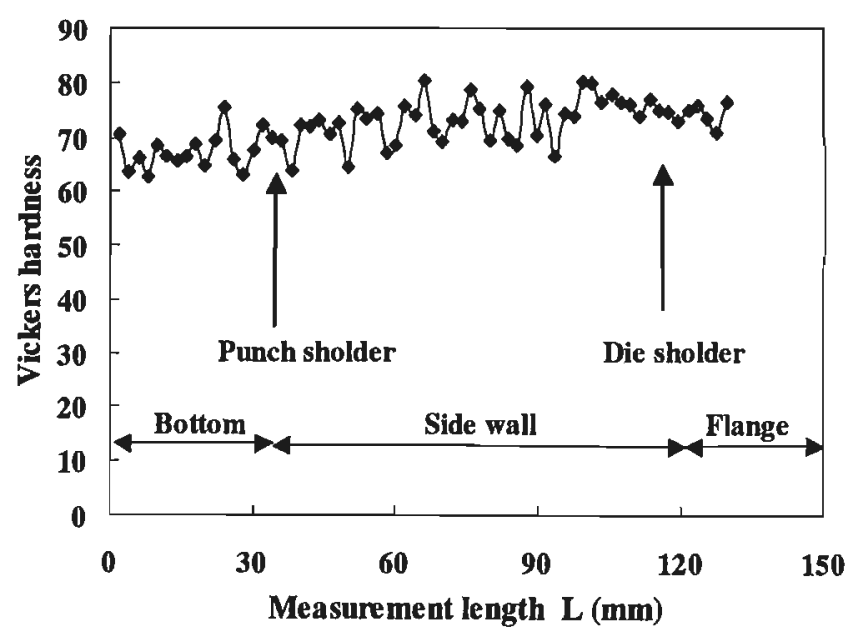

Fig. 14 Variation of Vickers hardness of drawing sample with distance from center of bottom.

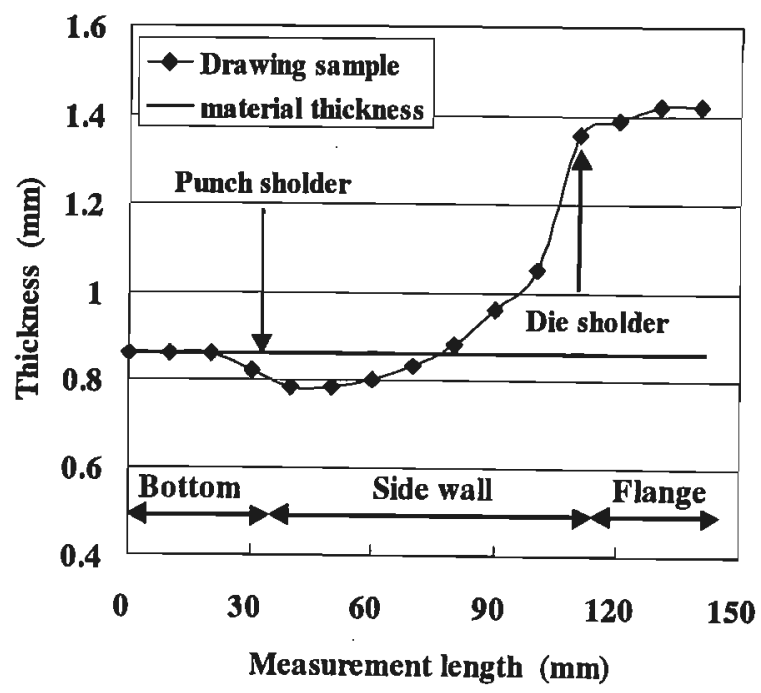

Fig. 15 Variation of thickness of drawing sample with distance from center of bottom.

光られる。パソチ底中心部の硬さは HV65～70程度であり， 加工前母材硬さに注潘等しい値となっている。さらに，半径 方向の引張りと曲げがかかるパンチ有部や材料のすべりこみ に伴って周方向に圧縮力が働くフランジ部に打いても HV65〜80程度であり，測定区間の全域にわたって際だった 硬さの変化が認められない。

ところで Fig. 14K示した加工はダイス温度が448 K であ ることより,フランジ部からダイス肩部に打いては活济448 Kで加工されたと見なせる。一方，Fig.6亿示した結果で は, 引張試験に括いて $448 \mathrm{~K}$ 以上で $n$ 值が注ぼ 0 亿収束して 特り, 加工硬化の点に打いては, これら単軸引張試験と深絞 り試験の結果はよく一致している。以上のことから，AZ31 合金は極めて加工硬化を生じにくい材料であると推測でき る。実際に絞り加工により製品を製作する場合には，しばし ば再絞り工程を必要とするが9), この上うに加工硬化現象が 見られない材料では皎り工程間の焼なましの必要がないため に，加エコストや工数の点でも有利であると考兄られる。

さらに Fig. 15では, 絞り加工品の板厚について示してい る。図中横軸の測定長 $L(\mathrm{~mm})$ は Fig. 14 と同様に较り加工 


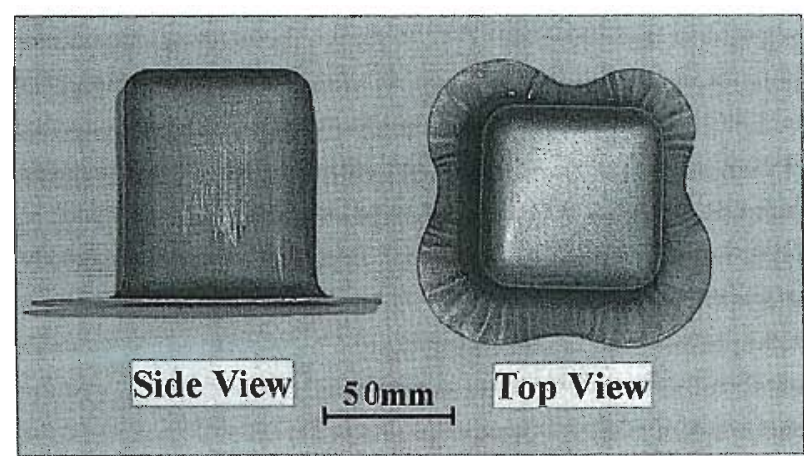

Fig. 16 Photograph of drawing sample.

品底中心部を 0 とし，底部半径方向から側壁部方向へと 10 $\mathrm{mm}$ 間隔で測定を行った。先程と同様に中心部 $(L=0)$ で は，ほぼ加工前ブランク材の板厚に等しいと考古られる。さ らに，パンチ肩部では引張変形下での曲げ戻しにより板厚の 減少が見られるとともにフランジ部では周方向の圧縮が支配 的となり，板厚の増加となって現れる傾向は，冷間圧延鋼板 やステンレス鋼板など，他の一般的な材料の板厚変化と同様 の傾向を示している10)。

現在，AZ91Dマグネシウム合金を用いてダイカスト製法 などによって製作されている携帯情報家電の筐体などは多く の場合，四角形状を呈している。Fig. 16には，これら製品 へのプレス成形加工の適用を想定し, 深絞り成形の応用例と して試みた角筒深皎りの加工サンプルを示す。成形条件は, ダイス温度 $498 \mathrm{~K}$ ，パンチ温度 $321 \mathrm{~K}$ で行った。角筒皎りは 円筒の場合とは異なり、コーナ部之直辺部ではフランジの材 料の流机込瓜に速度差が生じるためにこの部分でせん断変形 が生じることなどにより、コーナ部で破断を起こしやすい が，図で明らかなように不具合を生じずに絞り加工が可能で あることを確認した。

\section{4. 結言}

AZ31B-H24マグネシウム合金板について，その基本的な
材料特性と深校り成形性について検討を行うた結果，以下の 結論を得た。

（1）引張試験の結果，室温では10\%程度の伸びしか得られ ないが，温度を上げるに従って伸びが得られるよらになり， $473 \mathrm{~K}$ では80〜 90\%の高い伸びが得られ，r值は 1 に収束し, $n$ 值はほぼ 0 になる。

（2）深絞り成形性試験に特いては，ダイスの加熱によるマ グネシウム合金の間接的な加熱によって，材料の伸びを得る とともに変形抵抗を減らすことで皎り加工が可能となる。ダ イスの設定温度は拈执むね $473 \mathrm{~K}$ 以上で絞り比 $3.0 か ゙$ 得られ た。

（3）携帯情報家電の筐体などへのプレス成形加工の適用を 想定し，角筒の深絞り成形を試みた結果，円筒深絞り時の加 工温度と同等の条件による角筒深絞りも可能であることを確 認した。

これらの結果よりマダネシウム合金プレス加工の赛用化へ 端緒がついたと考学られる。

\section{参考 文 献}

1）金子純一，菅又 信，沼 政弘，西川泰久，大久保通則：塑 性加工学会春期講演論文集，(1997)，41.

2）長田直樹, 勝田基嗣：軽金属学会第89回秋期講演概要集, (1995), 179 .

3）大橋延夫，小野 筧，野原清彦：鉄と鋼，63（1977），252.

4）紫竹耕司, 山崎 淳, 渡部豈臣, 小會健一：塑性加工学会春 期講演論文集，(1991），239.

5）たと兊ば山口文雄：プレス技術，26 (1988)，22.

6）山田嘉昭，輸竹千三郎：塑性と加工，4（1963），341.

7）日本塑性加工学会編：ブレス加工便筧, 丸善, (1975), 336.

8）中川威雄, 阿部邦雄, 林豊 : 薄板のプレス加工, 実教出 版, (1991)，122.

9）渡部豈臣：プレス技術，24 (1986)，99.

10）中川威雄, 阿部邦雄, 林 豊: 薄板のブレス加工, 実教出 版, (1991), 104. 